\title{
Foreign portfolio capital flows and stock returns: a study of Brazilian listed firms ^
}

\author{
Tiago Rodrigues Loncan \\ PhD Student - Department of Accounting \& Finance, University of Strathclyde. \\ Adress: Strathclyde Business School - 6th floor, SW. 199 Cathedral Street, Glasgow, UK. G4 0OU \\ E-mail: tiago.loncan@gmail.com -tiago.rodrigues-loncan@strath.ac.uk
}

João Frois Caldeira

Professor - Department of Economics, Federal University of Rio Grande do Sul

Endereço: Av. João Pessoa, 52 - Sala 33B - $3^{\circ}$ andar - Porto Alegre/RS - Brazil

CEP: 90040-000 - E-mail: joao.caldeira@ufrgs.br

Recebido em 12 de setembro de 2014. Aceito em 06 de maio de 2015.

\begin{abstract}
This study analyzed the effect of foreign portfolio capital flows on stock returns of Brazilian listed firms through a 6-factors APT model, in which an additional risk factor for foreign portfolio capital flows was included. First, an aggregate analysis was conducted. The partial effect of foreign portfolio capital flows on the IBOVESPA index's returns was statistically significant and positive. Next, a disaggregate analysis was also implemented, in which portfolios of stocks were sorted by sector of economic activity, level of risk and level of corporate governance. Foreign portfolio capitals caused increases in returns especially for sectors related to commodities, industry and cyclical consumption. For the portfolios sorted by risk (in which the stocks' betas were used as a risk parameter for sorting), foreign capitals increased the returns of mid-high and high beta portfolios, but decreased the returns of low and low-mid beta portfolios. For corporate governance portfolios, the firms listed on the Novo Mercado segment (according to BMF\&Bovespa criteria) experienced a statistically significant revaluation effect. Overall, the results of the study provide support to the revaluation effect hypothesis.
\end{abstract}

\section{Keywords}

Foreign portfolio capital flows. Stock returns. Arbitrage pricing theory.

\section{Resumo}

Este estudo analisou o efeito dos fluxos de capital de portfólio nos retornos das ações de empresas brasileiras listadas em bolsa através de um modelo APT (Arbitrage Pricing Theory), no qual foi adicionado um fator de risco para os fluxos de capital de portfólio. Em uma análise agregada, o efeito parcial do fluxo de capital de portfólio no retorno do índice IBOVESPA foi estatisticamente significante e positivo. A seguir, uma análise desagregada foi realizada, na qual portfólios de ações foram formados utilizando o setor de atividade econômica, o nível de risco e o nível de governança corporativa. Fluxos de capital de portfólio causaram aumentos nos retornos especialmente para os setores de commodities, indústria e consumo cíclico. Para os portfólios de risco (nos quais o coeficiente beta das ações foi usado como parâmetro para classificação), os capitais

- João Caldeira wishes to thank CNPq (process 485561/2013-1) for financial support. 
de portfólio causaram aumentos nos retornos dos portfólios com beta médio-alto e alto, porém causaram decréscimos nos retornos dos portfólios com beta baixo-médio e baixo. Para os portfólios de governança corporativa, o portfólio de empresas listadas no segmento Novo Mercado teve o retorno afetado positivamente pelo fluxo de capitais. Em geral, os resultados do estudo corroboram a hipótese do "revaluation effect"

\section{Palavras-Chave}

Fluxos estrangeiros de capital de portfólio. Retornos das ações. Arbitrage pricing theory.

\section{Classificação JEL}

F320. G120. G150. G320.

\section{Introduction}

In the context of the globalization of financial markets, the Brazilian economy is an important destination for foreign portfolio capital flows. The recent economic growth experienced by Brazil, together with legal reforms in the financial markets and macroeconomic stabilization, especially in the last decade, attracted considerable flows of foreign portfolio capitals to the Brazilian financial market. The graph below illustrates the magnitude of the total assets held by foreign investors as a share of total BOVESPA (São Paulo Stock Exchange) market capitalization:

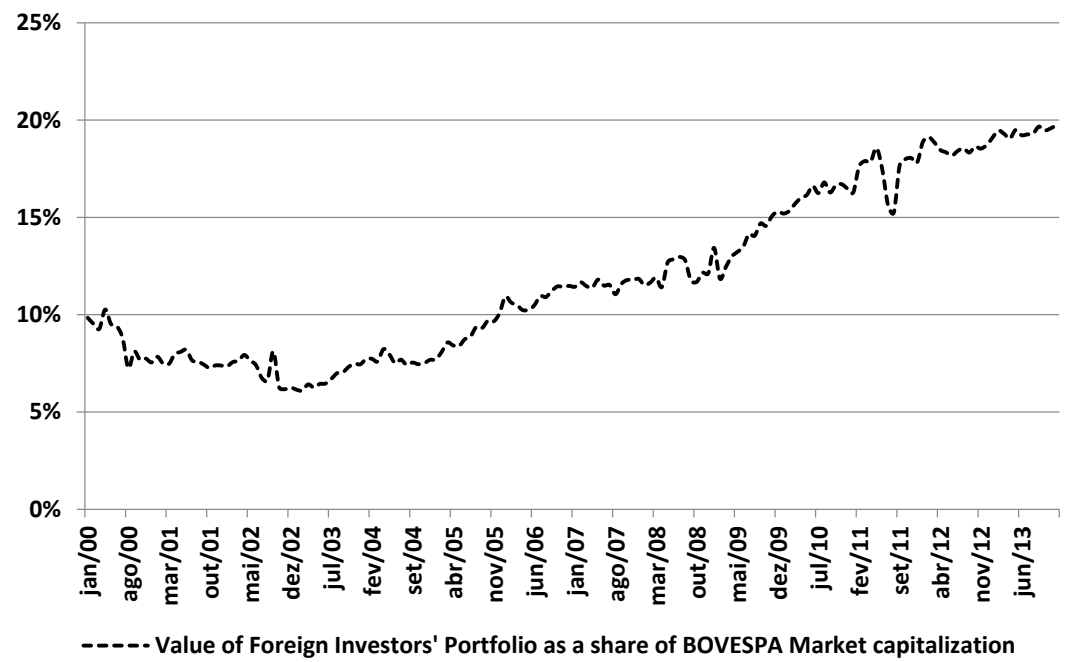

Graph 1 - Value of Foreign Investors' Portfolio as \% of Bovespa market capitalization - 2000-2013

Source: Comissão de Valores Mobiliários (Securities and Exchange Commission), 2014. 
As the graph shows, the market value of the portfolio of equities held by foreign investors as a share of total Bovespa market capitalization has grown substantially in the period between January of 2000 and December of 2013. At the beginning of the period, the market value of equities held by international investors accounted for roughly $10 \%$ of the market value of all equities traded in BOVESPA. Thirteen years after, this amount has doubled, reaching 20\%.

The first graph showed that the stock of equities held by foreign investors grew steadily over time. The graph next reports the evolution of net foreign portfolio capitals flows and stock market returns:

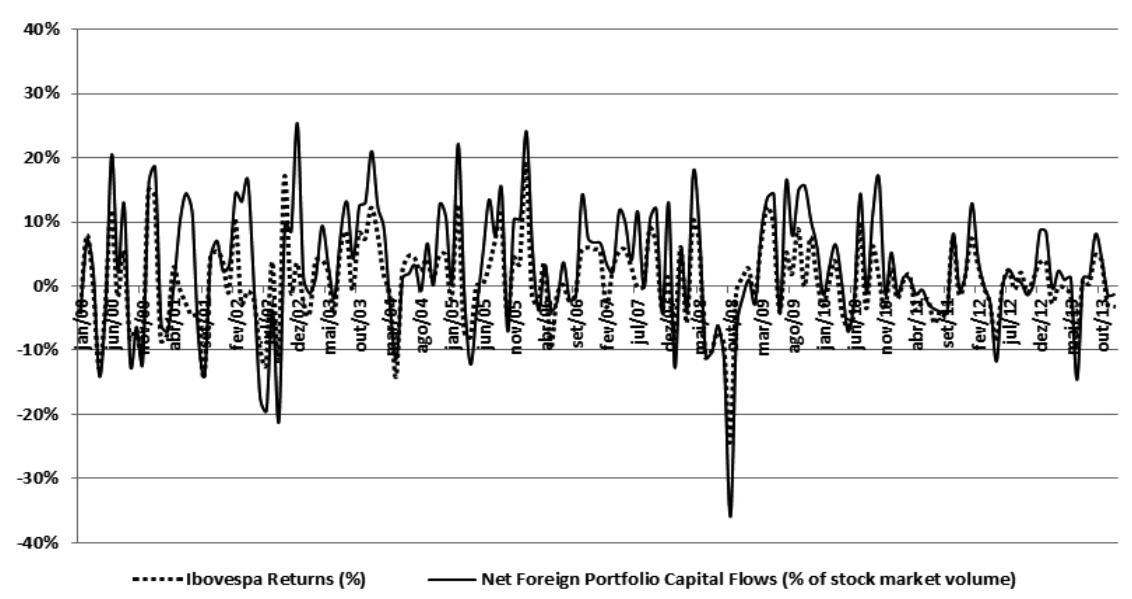

Graph 2 - Stock Market Returns and Net Foreign Portfolio Capital Flows in Brazil - 2000-2013

Source: Datastream (returns) and Central Bank of Brazil (foreign capitals), 2014.

When looking at foreign portfolio capital as a flow, instead of as a stock, the data shows that there was an interesting co-movement between net portfolio capital flows (subtracting outflows from inflows) and stock market returns. Also, net flows corresponded to an important fraction of total stock market traded volume, reaching values of over $20 \%$, what shows the relevance of foreign trading activity to the overall Brazilian stock market liquidity.

Following stock market liberalization (considering a previously segmented equity market), the inflow of international capitals tends to generate a process of risk sharing between domestic and internatio- 
nal investors, as before liberalization, only domestic investors could trade on local stocks. Henry (2000) argues that such process of risk sharing would lower the equity premium (which is the rate of return that investors claim on investments). As a result, the buying pressure over the stocks following the liberalization of the equity market drives returns upwards, the so-called "revaluation effect" (Errunza and Miller, 2000). As the theory suggests, and also as depicted by Graph 3, there is a positive and statistically significant correlation between net foreign portfolio capital flows and the returns of the IBOVESPA index, as shown in Graph 3:

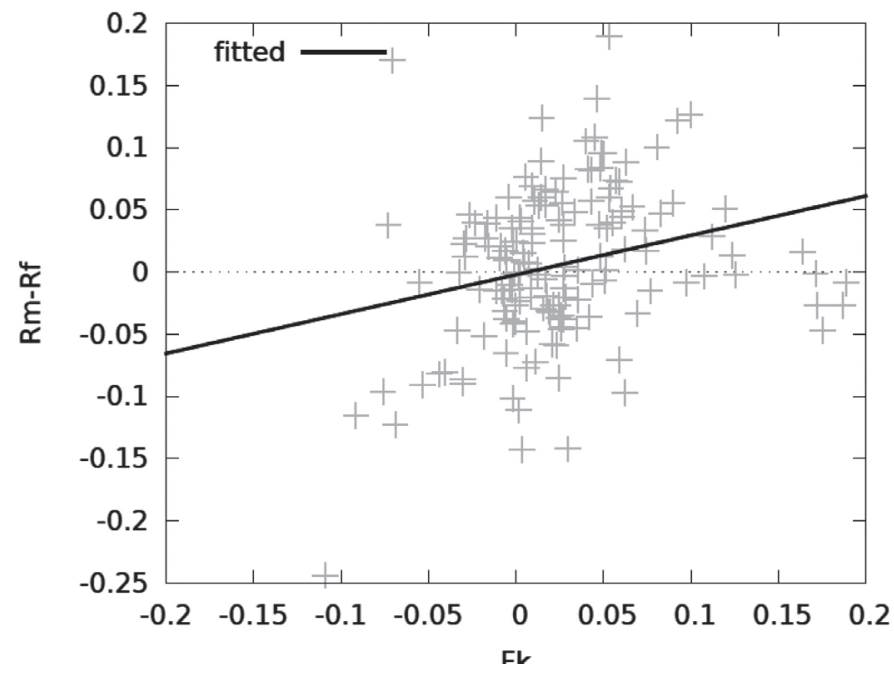

Graph 3 - Correlation: IBOVESPA Returns and Net Foreign Portfolio Capital Flows - 2000-2013

Source: Datastream (returns) and Central Bank of Brazil (foreign capitals), 2014

The correlation coefficient between the returns of the IBOVESPA index and net foreign portfolio capital flows is statistically significant and positive $(0.26 ; \mathrm{p}<0.01)$. It provides a first indication that stock returns might react positively to foreign portfolio capital flows, as it is contended by the theory. Another interesting fact to be noticed is that the cost of equity capital declined steadily during the last decade. The Graph next plots the evolution of the Dividend Yield (a proxy for the cost of equity capital): 


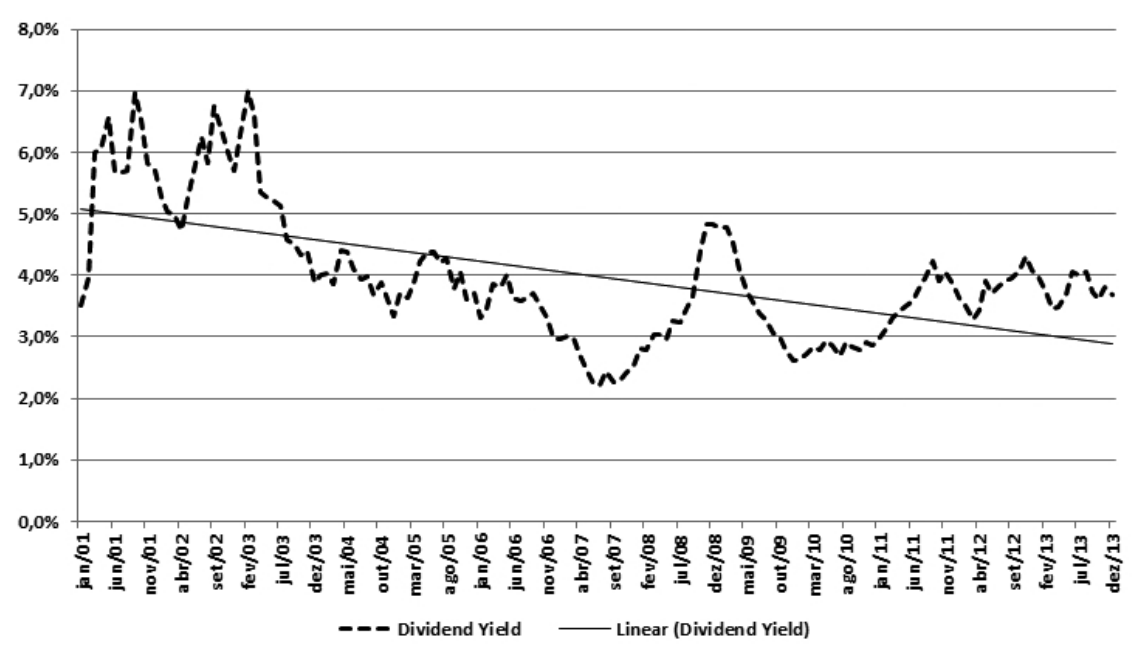

Graph 4 - IBOVESPA average Dividend Yield - 2001-2013

Source: Datastream, 2014

Indeed, one of the implications of foreign portfolio capital flows is a reduction in the cost of equity capital: as the buying pressure from foreign investor pressures stock prices up, the dividend yield declines. As Bekaert and Harvey (2000) suggest, stock prices changes dominate changes in the dividend yield, because the dividends payment pattern is likely to remain constant after liberalization processes.

The statistical evidence presented so far shows that foreign investors have increased their holdings on Brazilian stocks, that stock market returns and foreign portfolio capital flows exhibit significant correlation through time and that the cost of equity capital has declined during the last decade. These statistics provide the motivation for the present study: to analyze the effects of foreign portfolio capital flows on stock market returns and on the cost of equity capital of Brazilian listed firms. Specifically, the main objective of the paper is to study whether foreign portfolio capital flows increased stock market returns of Brazilian firms between 2001 and 2013.

Previous studies documented that foreign portfolio capital flows are associated to increases in stock market returns for the Brazilian stock market (Meurer, 2006; Franzen et al., 2009; Sanvicente, 
2014). These studies evaluated the effect of foreign portfolio capitals on aggregate stock market returns only, considering foreign portfolio capitals as one of the determinants of stock returns. The present study brings the following contributions:

(i) We interpret foreign portfolio capital flows as an additional risk factor in an Arbitrage Pricing Theory (APT) setting. As aggregate foreign portfolio capital flows can be seen as macroeconomic shocks, our view is that it is proper to consider these flows as risk factors. In our model, we control for important risk factors known for affecting stock returns (namely SMB, HML, WML and IML), which were absent in prior studies.

(ii) We conduct an aggregate analysis first, but we also do a firm-level (portfolio-level) analysis, which was so far neglected by all studies covering the Brazilian context, whereas international studies have considered this important dimension of analysis (see Chari and Henry, 2004; Patro and Wald, 2005; Christoffersen, Chung \& Errunza, 2006). Such international studies focused essentially on the role of firm size as a mediator of the revaluation effect. We study the role of other variables, which were not considered in prior studies: sector of economic activity, level of risk and corporate governance. As the results indicate that the revaluation effect differs across portfolios both in magnitude and sign, there is evidence that portfolio (firm) characteristics matter.

(iii) We assess the effect of foreign capitals on the aggregate cost of equity capital directly, be estimating a model for measuring the partial effect of net foreign capitals on the dividend yield. Prior studies assessed the effect of foreign capitals on the cost of capital only indirectly, through stock prices.

The sequence of the paper is structured as follows: Section 2 presents a literature review related to the effects of foreign portfolio capital flows on stock returns and the cost of capital. Section 3 describes the data and the variables used in the study. Section 4 brings an asset pricing analysis, in which regressions were used to estimate the impact of foreign capitals on excess returns of sector-sorted, risk-sorted and governance-sorted portfolios of stocks. In section 5 the results are discussed, and finally section 6 concludes. 


\section{Literature Review}

\subsection{Effects of foreign portfolio capitals on stock returns and on the cost of equity capital}

\subsubsection{International empirical evidence}

The majority of papers that studied the effects of foreign portfolio capital flows on the cost of equity capital at firm level evaluated how the inflow of foreign capitals that followed key liberalization events affected stock market returns (Errunza and Miller, 2000, Bekaert and Harvey, 2000; Henry, 2000; Chari and Henry, 2004, 2008; Patro and Wald, 2005; Christoffer, Chung and Errunza, 2006, among others). The main methodology used on these papers was the event study: stock market returns were compared before and after liberalization dates or events. The general conclusion is that the liberalization of equity markets is associated to an increase in stock market returns, which ultimately leads to a decrease in the cost of equity capital.

Bekaert and Harvey (2000) analyzed the change in the dividend yield before and after the liberalization of the equity market for various emerging economies. The dividend yield was obtained by dividing the dividends paid by the price of the stock. They also assumed that that the dividend growth process does not change after liberalization, besides relying on the usual assumption of constant growth rate of dividends. The authors estimated a regression between the dividend yield and a measure of market liberalization (they used various measures as the stock of equities held by foreign investors, a dummy variable for liberalization events, among others). They found that the dividend yield declined as a function of the liberalization process, providing support for the hypothesis that foreign capital flows reduce the cost of equity capital.

Errunza and Miller (2000) studied the impact of foreign capitals on the cost of equity capital analyzing whether firms from developing and developed countries that issued ADRs (American Depositary Receipts) in the U.S. stock market experienced reductions on the cost of equity capital. They found that after firms issued ADRs in the US stock market, stocks experienced higher returns. This finding supports the hypothesis of equity cost reduction due to risk -sharing between domestic and international investors. 
Foerster and Karolyi (2000) also tested the key prediction of the market segmentation hypothesis, which claims that firms involved in Global Equity Offerings (GEOs) should benefit from the access to globally integrated markets, by gaining access to capital at a lower cost. They also studied ADR offerings, adding to the study the possibility of another type of depositary receipt offering which is the private placement orders under the Rule 144A (only available to specific "sophisticated" investors), which differs from normal public ADR offerings in the sense that private placement equity offers are less subject to complying to US regulations, and hence is a simplified way for foreign firms to access the US equity market. ADR offerings were associated to positive long run returns, but that ADRs under rule 144A (private placement) were associated to negative returns. The main findings were that listing abroad increased stock market returns, and also that investors rewarded the firms that made efforts to comply with the more rigorous US accounting standards (as the public offering resulted in higher returns than the private placement).

Cheri and Henry $(2004,2008)$ studied whether the revaluation effect could be split between firm specific characteristics and the common shock to the whole equity market. The common shock is the risk sharing that affects all firms, regardless of the status of the firm in the stock market as being of an investible firm (a firm that foreign investors would like to add to their portfolio after liberalization) or a non-investible firm .The idea is that after liberalization, there is a common shock to expected returns, because as the country moves from being a segmented market to an integrated market, the risk-free rate falls. Authors found that investible firms experienced an average stock price revaluation of $15 \%$, out of which $40 \%$ of this effect is due to firm-specific risk-sharing characteristics. Firm level characteristics mediated the process of equity cost reduction, suggesting that the equity cost reduction benefit did not spillover equally across all listed companies.

Patro and Wald (2005) analyzed the impact of stock market liberalization for 18 emerging markets. The authors found that after the liberalization process, the inflow of portfolio capitals caused expected returns to fall, implying a lower cost of equity capital, according to predictions of risk sharing between domestic and international investors. Dividend yields dropped substantially after liberalization. 
During the liberalization process, smaller firms showed higher returns, suggesting that the revaluation effect for small firms is higher.

Christoffersen, Chung and Errunza (2006) also estimated the revaluation effect after liberalization processes. The authors checked whether the returns yielded by stocks were higher when compared to a global returns benchmark, and also if the returns were comparatively higher for larger firms. The authors found that there is a positive revaluation effect, being the returns on stocks higher than the global benchmark during the liberalization of capital flows. Also, their results support the hypothesis that large firms experience higher revaluation effects than small firms, the opposite result found by Patro and Wald (2005).

\subsubsection{Brazilian empirical evidence}

Most of the Brazilian studies evaluated the impact of foreign portfolio capitals on the aggregate stock market return. The main conclusion of these studies is that foreign portfolio capital flows are associated to increases in stock market returns, providing support to the hypothesis of the revaluation effect and consequently equity cost reduction.

Tabak (2003) used VAR and cointegration analysis to study the relationship between foreign capitals and stock market returns. He showed that inflows of foreign portfolio capitals to the Brazilian stock market had a huge increase after 1994 (the date that marks macroeconomic stabilization), and that these inflows seem to be induced by increases in the stock market index. Also, these flows helped to increase the efficiency of the Brazilian stock market. He found evidence of cointegration between the IBOVESPA index and international portfolio flows, concluding that the variables have a long-run equilibrium relationship. As for the direction of the causality, he found evidence that higher stock returns induce foreign capital flows.

Meurer (2006) studied the influence of net inflows of resources from international investors on the Brazilian stock market (BOVESPA), using VAR analysis. The author found that variations in the IBOVESPA index precede a variation in the total participation 
of foreign investors in the total market capitalization of Brazilian stock market, directly or indirectly. The direct effect occurs when variations in the index precede variations in the share of international investors in the market. The indirect effect materializes from variation in the index to a higher liquidity in the market, and finally higher liquidity attracting more international investors. Hence, investors observe alterations in the index, and based on these alterations they decide whether to invest in stocks or not.

As a description of the behavior shown by international investors in the Brazilian stock market, Meurer (2006) found that portfolio flows are higher when the index is low, and the outflows are higher when the index is high, showing that portfolio investors are trying to operate in the opposite way with respect to the market, buying stocks when prices are low and selling when prices are high, chasing profitable opportunities. But overall, the contemporaneous correlation between stock returns and foreign capitals was positive, suggesting that foreign portfolio capital flows are contemporaneously associated to higher returns.

Franzen et al. (2009) studied how the portfolio investment flows to the Brazilian stock market are affected by the return of IBOVESPA index, exchange rate variation, basic interest rate (SELIC) and country risk, between 1995 and 2005, in a monthly base. The methodology employed was VAR and VECM analysis. Their results were in synergy with those reported by Meurer (2006) with respect to the rational behavior of international investors, as they also found that investors entered the market after falls and left after rises of IBOVESPA index. Authors found that portfolio investments are positively related to lagged returns of the index, showing that international investors consider past returns when building their investment strategies.

Reis, Meurer e Da Silva (2010) studied the relationship between the Brazilian stock market returns and foreign portfolio investments using a linear regression model. They regressed the IBOVESPA stock market returns on the first difference of the value of equities held by foreign investors as a share of BOVESPA market capitalization. They also added other controlling variables, as the exchange rate between the Brazilian real and the US dollar, the returns to Global equity markets, the spread to the Brazilian bonds (EMBI+), conside- 
ring also lags for the independent variables. Their results supported a positive contemporaneous relationship between stock market returns and foreign portfolio capital inflows. However, they did not find evidence that foreign capitals Granger-cause returns, but instead found that past returns Granger-cause contemporaneous inflows. They concluded that foreign investors are feedback traders: they observe returns first, and next decide on their investment strategy. Sanvicente (2014) contends that the relationship between the Brazilian stock market returns and foreign portfolio capitals can be described in three different forms. The first possibility is in synergy with the argument of Reis, Meurer and da Silva (2010), as foreign investors would be "trend chasers", buying Brazilian stocks after past returns were found to be attractive (feedback trading).

The second possibility is that actually portfolio capital flows cause returns, which is called the information contribution argument. The main rationale for this argument is that foreign institutional investors are better informed than domestic investors, so they anticipate better profit opportunities, buying stocks first, driving prices up, and profiting from capital gains. The third theoretical rationale to describe the relationship between the variables is the mutual feedback.

Sanvicente (2014) employed a simultaneous equation test to study the relationship between stock market returns and net foreign portfolio capital flows. Foreign capital flows caused excess stock market returns, as there is positive contemporaneous correlation between the two variables, but also because the first, second and third lag of foreign capital flows were positively correlated to stock market returns.

On the other hand, for the equation modeling foreign capital inflows, he found only contemporaneous correlation between the two variables, and no effect of lags of returns on foreign capitals. Therefore, the results supported the information contribution argument. 


\section{Data description}

\subsection{Stock market data}

The sample consists of stocks traded at the BOVESPA stock exchange. As of December of 2013 (the last month comprised by the sample), 363 firms were listed in the stock exchange. After excluding stocks from financial firms, and also after removing outliers, the final sample consists of 191 stocks. Outliers were removed when a given stock had more than 5 consecutive months of missing data for returns (returns were collected from the Datastream and Economatica databases).

The sampling period is from January 2001 to December 2013. Not all 191 stocks were listed contemporaneously, so firms were added to the analysis as they got listed in the stock market. Only firms that were active in December 2013 were included in the sample, so firms that were de-listed between 2001 and 2013 were excluded from the analysis.

The approach used in the study was to sort the 191 stocks in the sample by portfolios. First, the sorting was made according to the sector of the economy that each stock belongs, being the stocks grouped in 9 different portfolios (following the BMF\&Bovespa - São Paulo Stock Exchange classification criteria). Next, the firms were sorted according to their level of risk, using the Beta coefficient of stocks as a measure of riskiness. Four portfolios were formed based on the distribution of Betas for the 191 firms. Finally, four Corporate Governance portfolios were sorted based on the classification from BMF\&Bovespa: Novo Mercado (New Market), N1, N2 and Bovespa Tradicional. The returns were valued-weighted using the stock's market capitalization as a weighting parameter. 


\subsection{Variables}

The next table summarizes the variables used in the study:

Table 1 -Variables

\begin{tabular}{|c|c|c|c|c|}
\hline Variable & Legend & Operationalization & Interpretation & Source \\
\hline Ibovespa Returns & $R m$ & Monthly returns of the index & $\begin{array}{l}\text { Equity premium for } \\
\text { the Brazilian market }\end{array}$ & NEFIN USP \\
\hline Swap pre-DI & Rf & $\begin{array}{l}\text { Monthly spread on the interbank } \\
\text { deposit rate }\end{array}$ & $\begin{array}{l}\text { Proxy for Brazilian } \\
\text { risk-free rate }\end{array}$ & NEFIN USP \\
\hline Excess Ibovespa Returns & $R m-R f$ & $\begin{array}{l}\text { Monthly difference between market } \\
\text { returns and risk free rate }\end{array}$ & $\begin{array}{c}\text { Excess return on } \\
\text { the Brazilian stock } \\
\text { market }\end{array}$ & NEFIN USP \\
\hline $\begin{array}{l}\text { Excess S\&P } 500 \text { Compos- } \\
\text { ite returns }\end{array}$ & $R w f$ & $\begin{array}{l}\text { Monthly returns of the índex minus } \\
\text { U.S risk fre rate (3-months T-bill } \\
\text { returns) }\end{array}$ & $\begin{array}{l}\text { Proxy for global } \\
\text { returns }\end{array}$ & Datastream \\
\hline $\begin{array}{l}\text { Net Foreign Portfolio } \\
\text { Capital flows }\end{array}$ & $F k$ & $\begin{array}{l}\text { Monthly net foreign portfolio capital } \\
\text { flows (inflows minus outflows) as } \\
\text { a percentage of total stock market } \\
\text { traded volume }\end{array}$ & $\begin{array}{l}\text { Measure of foreign } \\
\text { portfolio investor's } \\
\text { activity on the stock } \\
\text { market }\end{array}$ & $\begin{array}{c}\text { Central Bank } \\
\text { of Brazil }\end{array}$ \\
\hline $\begin{array}{l}\text { Excess Returns for } \\
\text { portfolio } i\end{array}$ & Rit & $\begin{array}{l}\text { Monthly difference between the } \\
\text { returns to portfolio i and risk free rate }\end{array}$ & $\begin{array}{l}\text { Monthly Returns for } \\
\text { portfolio } i \text { in time } t\end{array}$ & Datastream \\
\hline Beta & $\beta_{i}$ & $\begin{array}{l}\text { Covariance between the returns of a } \\
\text { given portfolio and the market returns } \\
\text { divided by the variance of market re- } \\
\text { turns (the measure is net of the partial } \\
\text { effect of foreign capitals on returns) }\end{array}$ & $\begin{array}{l}\text { Proxy for firms' } \\
\text { (portfolios') risk }\end{array}$ & - \\
\hline Small minus Big & $S m b$ & $\begin{array}{c}\text { Excess returns earned by a portfolio } \\
\text { of small stocks over a portfolio of big } \\
\text { stocks }\end{array}$ & $\begin{array}{l}\text { Smb risk factor in } \\
\text { APT models }\end{array}$ & NEFIN USP \\
\hline High minus Low & $\mathrm{Hml}$ & $\begin{array}{c}\text { Excess returns earned by a portfolio } \\
\text { of growth stocks over a portfolio of } \\
\text { value stocks }\end{array}$ & $\begin{array}{c}\text { Hml risk factor in APT } \\
\text { models }\end{array}$ & NEFIN USP \\
\hline Winners minus Losers & $W m l$ & $\begin{array}{l}\text { Excess returns earned by a portfolio } \\
\text { of winning stocks over a portfolio of } \\
\text { losing stocks }\end{array}$ & $\begin{array}{l}\text { Wml risk factor in } \\
\text { APT models }\end{array}$ & NEFIN USP \\
\hline Illiquid minus Liquid & $I m I$ & $\begin{array}{l}\text { Excess returns earned by a portfolio } \\
\text { of illiquid stocks over a portfolio of } \\
\text { liquid stocks }\end{array}$ & $\begin{array}{l}\text { Iml risk factor in APT } \\
\text { models }\end{array}$ & NEFIN USP \\
\hline Dividend Yield & Dy & $\begin{array}{c}\text { Dividends paid divided by stock } \\
\text { prices (averaged across IBOVESPA } \\
\text { constituents) }\end{array}$ & $\begin{array}{l}\text { Proxy for the cost of } \\
\text { equity capital }\end{array}$ & Datastream \\
\hline
\end{tabular}

The main independent variable used in the study is net portfolio capital flows as a ratio of total stock market traded volume (Fk). It is important to remark that only the foreign capitals directed to the equity market are captured by this variable, or in other words, it measures how much foreign portfolio capitals were used to buy or sell stocks. The measure does not include FDI flows, fixed income flows, whether private or public debt bonds, derivatives flows and finally loans from international organizations like the IMF. 
The choice for using net foreign portfolio capitals (inflows minus outflows), instead of using portfolio inflows and outflows, considered two factors. First, net flows are stationary in level. On the other hand, both inflows and outflows grew steadily over time, so the variables are non-stationary in level. As stock returns are stationary, using the first-difference of inflows or outflows on a regression having returns as a dependent variable would yield a marginal effect of foreign capitals on excess returns of difficult interpretation, instead of a direct marginal effect as we can obtain by using a variable in level.

The second reason has to do with the characteristics of this study. Net inflows provide a measure of the resulting effect of buying and selling stocks from foreign investors, whereas inflows measure only the buying pressure whereas outflows measure only the selling pressure. If we want to evaluate the ultimate effect of foreign capitals on returns, it is important to allow for both buying and selling pressure. Since inflows and outflows are highly correlated (like in this sample), they cannot be used in the same equation (for multicollinearity reasons), so the best solution was to use net flows.

\subsection{Portfolios}

The motivation to estimate the effect of foreign capitals using sectors portfolios comes from three rationales: first, Damodaran (2007) argues that usually firms from the same sector have similar exposure to macroeconomic shocks. Thus, if we consider that the inflow or outflow of foreign capitals is a macroeconomic shock, firms from the same sectors should be influenced by these shocks in a similar way.

Second, firms from the same sector of activity share similar characteristics, like size, capital structure, profitability and investment, among others (Smart et al., 2007). Third, the economic growth experienced by the Brazilian economy in the recent years was much fostered by some sectors of economic activity, like: (i) consumption due to public policies of income transfers to low-income agents and a substantial increase in credit availability, and (ii) commodity prices, as the decade between 2000 and 2010 was marked by a considerable appreciation of commodity prices. Thus it is interesting to study 
whether the exposure of returns to foreign capitals was different across various sectors of economic activity.

For the risk-sorted portfolio analysis, the grouping of stocks in different portfolios was based on the level of exposure to the systematic risk (betas). Foreign institutional investors diversify globally, using different markets for hedging purposes. Since the beta coefficient measures the sensitivity of a given stock (portfolio) to market returns, it also measures the exposition of that portfolio to the local market systematic risk. In principle, foreign investors should be interested in buying stocks whose risk is diversifiable, instead of stocks carrying much idiosyncratic risk (low betas). Looking at the revaluation effect across risk-sorted portfolios, we can assess foreign investors' preference for diversifiable risk.

The corporate governance portfolios grouped stocks according to their level of corporate governance as per the BMF\&Bovespa criteria. Stulz (2005) argues that foreign institutional investors are more inclined to hold stocks from firms following best practices of corporate governance, as these practices help reducing asymmetries of information between management and shareholders. Therefore, firms following best practices of corporate governance should benefit more from foreign portfolio capital flows, when compared to firms following less clear corporate governance rules.

\subsection{Descriptive statistics for time series}

Table 2 -Descriptive Statistics - Jan/2001 to Dec/2013

\begin{tabular}{|c|c|c|c|c|c|}
\hline & Mean & Std dev & Min & Max & $\boldsymbol{n}$ \\
\hline $\boldsymbol{R m}-\boldsymbol{r f}$ & $0,60 \%$ & $6,20 \%$ & $-24,30 \%$ & $18,90 \%$ & 156 \\
\hline $\boldsymbol{S M B}$ & $0,30 \%$ & $4,80 \%$ & $-17,10 \%$ & $18,50 \%$ & 156 \\
\hline $\boldsymbol{H M L}$ & $0,70 \%$ & $4,70 \%$ & $-13,40 \%$ & $14,20 \%$ & 156 \\
\hline $\boldsymbol{W M L}$ & $1,00 \%$ & $5,70 \%$ & $-23,90 \%$ & $17,20 \%$ & 156 \\
\hline $\boldsymbol{I M L}$ & $0,40 \%$ & $4,57 \%$ & $-14,70 \%$ & $14,50 \%$ & 156 \\
\hline $\boldsymbol{R} \boldsymbol{f}$ & $1,10 \%$ & $0,40 \%$ & $0,40 \%$ & $3,60 \%$ & 156 \\
\hline $\boldsymbol{F} \boldsymbol{k}$ & $2,40 \%$ & $5,00 \%$ & $-11,50 \%$ & $21,70 \%$ & 156 \\
\hline $\boldsymbol{D} \boldsymbol{y}$ & $3,90 \%$ & $1,00 \%$ & $2,00 \%$ & $7,00 \%$ & 156 \\
\hline $\boldsymbol{R} \boldsymbol{w}$ & $0,20 \%$ & $4,50 \%$ & $-18,50 \%$ & $10,20 \%$ & 156 \\
\hline
\end{tabular}

Source: Economatica, Datastream, CVM, BACEN and NEFIN-USP 
Mean returns are not so much informative because we are looking at a long time series, but it is worth noting that returns both to the stock market index (Rm-rf) and other factors (Smb, Hml, Wml and Iml) were positive on average. The average risk-free rate was $1.10 \%$, whereas the average dividend yield for the Ibovespa index (cost of capital) was $3.9 \%$.

Net foreign porfolio capital flows (Fk) were positive in the period, as there was an average inflow of portfolio capitals corresponding to $2.5 \%$ of total stock market traded volume. In the month in which the highest inflow was observed, it accounted for $21 \%$ of total stock market traded volume. For the month in which the highest outflow was reported, it accounted for $11.0 \%$ of total stock market traded volume. Therefore, the participation of foreign investors in the Brazilian stock market is indeed substantial.

Table 3 - Correlation Matrix for time series variables - Jan/2001 to Dec/2013

\begin{tabular}{|c|c|c|c|c|c|c|c|c|c|}
\hline & $R m-r f$ & SMB & $H M L$ & WML & IML & $R f$ & $F k$ & Dy & $R w$ \\
\hline$R m-r f$ & 1 & & & & & & & & \\
\hline$S M B$ & $0.18^{\star *}$ & 1 & & & & & & & \\
\hline$H M L$ & $-0,02$ & 0,06 & 1 & & & & & & \\
\hline$W M L$ & $-0.29^{\star \star \star}$ & $-0.32^{\star \star \star}$ & $-0,045$ & 1 & & & & & \\
\hline$I M L$ & $-0,09$ & $0.71^{\star \star \star}$ & $0.17^{\star *}$ & $-0,04$ & 1 & & & & \\
\hline$R f$ & 0,06 & 0,11 & $0.18^{* *}$ & -0.01 & 0,05 & 1 & & & \\
\hline$F k$ & $0.28^{\star \star *}$ & $0.23^{\star \star \star}$ & 0,09 & -0.08 & 0,10 & 0,04 & 1 & & \\
\hline$D y$ & $-0.15^{* * *}$ & 0,03 & 0,00 & -0.02 & 0,03 & $0.51^{* \star *}$ & $-0,12$ & 1 & \\
\hline$R w$ & $0.67^{\star \star *}$ & 0,10 & $-0,09$ & $-0.37^{\star \star *}$ & $-0.16^{* \star}$ & $-0,11$ & $0.26^{* \star *}$ & $-0.17^{\star *}$ & 1 \\
\hline
\end{tabular}

*** Significant at 0.01 level; ** Significant at 0.05 level; *Significant at 0.1 level

The correlation matrix shows positive association between the Brazilian stock market returns, $\mathrm{Rm}$, and net foreign portfolio capital flows, Fk (0.28). The interpretation is that net foreign portfolio capital flows are associated to a contemporaneous increase in aggregate stock market returns. This finding is a first indication that net foreign portfolio capitals could be associated to higher stock returns. As the correlation is positive, the behavior of foreign investors in the period between 2001 and 2013 seems to be of exerting a buying pressure on Brazilian stocks, pushing returns upwards. It is also worth to notice that the returns to the Brazilian stock market are correlated to the returns to the global market (0.67). 


\subsection{Descriptive statistics for portfolios}

Table 4 - Descriptive Statistics for Portfolios' returns

\begin{tabular}{|c|c|c|c|c|c|c|}
\hline & Mean & Std dev & Min & Max & Corr (Ri,Fk) & \#stocks \\
\hline \multicolumn{7}{|l|}{ Economic Sectors } \\
\hline Cyclical consumption (Cyc) & $0,10 \%$ & $8,30 \%$ & $-26,10 \%$ & $23,60 \%$ & $0.28^{\star \star *}$ & 33 \\
\hline Industrial goods (IG) & $0,40 \%$ & $8,24 \%$ & $-27,00 \%$ & $20,60 \%$ & $0.26^{\star \star *}$ & 16 \\
\hline Basic materials (BM) & $0,40 \%$ & $8,13 \%$ & $-32,70 \%$ & $19,40 \%$ & $0.31^{* * *}$ & 27 \\
\hline Real estate (RE) & $0,40 \%$ & $4,57 \%$ & $-14,70 \%$ & $14,50 \%$ & $0.24^{* * *}$ & 30 \\
\hline Public Utilities (PU) & $0,30 \%$ & $9,80 \%$ & $-43,30 \%$ & $36,60 \%$ & $0.27^{* \star *}$ & 27 \\
\hline Telecom (TC) & $-0,70 \%$ & $6,70 \%$ & $-18,50 \%$ & $19,10 \%$ & -0.013 & 4 \\
\hline Construction and Transport (CT) & $0,40 \%$ & $8,70 \%$ & $-34,50 \%$ & $24,40 \%$ & $0.14^{*}$ & 19 \\
\hline Oil and Gas (OG) & $-0,40 \%$ & $9,70 \%$ & $-39,80 \%$ & $20,80 \%$ & $0.26^{\star \star \star}$ & 4 \\
\hline Non-cyclical consumption (N_cyc) & $0,60 \%$ & $5,90 \%$ & $-20,10 \%$ & $18,30 \%$ & 0.06 & 29 \\
\hline \multicolumn{7}{|l|}{ Risk } \\
\hline Beta 1 (low) & $0,70 \%$ & $5,20 \%$ & $-14,10 \%$ & $17,80 \%$ & 0.13 & 47 \\
\hline Beta 2 (low-mid) & $0,20 \%$ & $5,80 \%$ & $-17,80 \%$ & $15,70 \%$ & $0.26^{\star \star \star}$ & 46 \\
\hline Beta 3 (mid-high) & $0,00 \%$ & $7,30 \%$ & $-33,50 \%$ & $18,10 \%$ & $0.28^{* * *}$ & 50 \\
\hline Beta 4 (high) & $0,15 \%$ & $10,30 \%$ & $-38,90 \%$ & $22,70 \%$ & $0.31^{* * *}$ & 48 \\
\hline \multicolumn{7}{|l|}{ Corporate Governance } \\
\hline Novo Mercado (NM) & $0,20 \%$ & $7,40 \%$ & $-28,30 \%$ & $20,30 \%$ & $0.28^{* * *}$ & 105 \\
\hline N1 & $0,00 \%$ & $6,90 \%$ & $-26,20 \%$ & $15,90 \%$ & $0.29^{* * *}$ & 21 \\
\hline N2 & $0,80 \%$ & $7,40 \%$ & $-33,20 \%$ & $19,60 \%$ & $0.21^{\star \star \star}$ & 10 \\
\hline Tradicional Bovespa (TB) & $0,00 \%$ & $6,80 \%$ & $-30,90 \%$ & $16,40 \%$ & $0.26^{\star \star \star}$ & 55 \\
\hline
\end{tabular}

The descriptive data on the portfolios provide information on the number of stocks in each portfolio. Overall the number of firms is well distributed across different portfolios, except for the corporate governance case, where the Novo Mercado segment dominates with 105 firms. The fifth column shows the correlation between returns and Foreign Capitals: as the correlation is statistically significant for the majority of portfolios, it provides a first indication that the effect of foreign capitals on returns holds also at portfolio level. But since these are not partial correlations, one cannot tell whether it is measuring the specific correlation between the portfolio and the foreign flow or if it captures the correlation of aggregate returns and foreign flows through the portfolios returns. The regression analysis shown later will be helpful in disentangling these effects, because we include aggregate returns as a control in the estimations. 


\section{Empirical analysis}

\subsection{Methodology}

The widely used method in prior studies for the Brazilian case was time series analysis using Vector Autoregressive Analysis. However, this method does not capture properly the net partial effect of foreign portfolio capital flows on the excess returns of portfolios when controlling for the most important risk factors affecting returns. For this reason we employed an appropriate asset pricing model: an Arbitrage Pricing Theory (APT) model, including risk factors as controls for systematic risk (beta), small minus big spread (SMB), high minus low spread (HML), winners minus losers spread (WML) and illiquid minus liquid spread (IML).

Two studies were conducted: one at the aggregate level and another at disaggregate (portfolio) level. For the aggregate analysis, first we look at the effect of foreign capitals on stock market aggregate returns. For this regression, excess returns to the IBOVESPA index (Rm-Rf) is the dependent variable, net Foreign Portfolio Capital Flows (Fk) is the main explanatory variable and the additional risk factors S\&P500, SMB, HML, WML and IML are controls. The main controlling variable is the return to S\&P500, as a proxy for global systematic risk (as in Reis, Meurer and Da Silva, 2010). Additionally, year dummies were included as controls (Dt). The first model estimated is as follows:

$$
\begin{aligned}
R_{m t}-r f_{t}=\alpha & +\beta\left(R w_{t}-r f w_{t}\right)+s\left(S m b_{t}\right)+h\left(H m l_{t}\right)+w\left(W m l_{t}\right) \\
& +l\left(I m l_{t}\right)+\gamma\left(F k_{t}\right)+\delta_{i, n}\left(\sum_{01}^{13} D_{t}\right)+\varepsilon_{t}
\end{aligned}
$$

We are interested essentially on the interpretation of the gamma coefficient, which measures the partial effect of net foreign capitals on portfolios returns. The literature suggests that foreign capitals are associated to increases in returns. As a previously segmented market integrates to the global equity market, the flow of foreign portfolio investments pressures stock prices up, the so-called revaluation effect (Henry, 2000; Patro and Wald, 2005). Therefore, the expected relationship between returns and net foreign capitals is of an increasing effect. 
A second model for the aggregate analysis was also estimated, having the dividend yield as the dependent variable, as a proxy for the cost of equity capital. ${ }^{l}$ The main explanatory variable is foreign capitals (Fk). For the dividend yield is highly serially correlated when calculated monthly, we included one lag of the dividend yield to control for autocorrelation. Besides that, we also included time dummies. The model for the dividend yield is shown below:

$$
D y_{t}=\alpha+\beta\left(D y_{t-1}\right)+\gamma\left(F k_{t}\right)+\delta_{i, n}\left(\sum_{01}^{13} D_{t}\right)+\varepsilon_{t}
$$

The interpretation for the gamma coefficient in this second model differs from the first model presented. Here, we are assessing the effect of net foreign capitals on the cost of equity directly. As theory suggests that the cost of capital declines as a function of capital flows, we expect the gamma coefficient to be negative for this regression.

Next, we estimated regressions similar to model 1 for the portfolios. The model is essentially the same as the one estimated for the aggregate dimension, but using the IBOVESPA excess returns as the main control for systematic risk (a national beta, instead of the global beta used before). The other risk factors are the same. Once again time dummies were included as controls. The model applied for the portfolios is shown next:

$$
\begin{gathered}
R_{i t}-r f_{t}=\alpha_{i}+\beta_{i}\left(R m_{t}-r f_{t}\right)+s_{i}\left(S m b_{t}\right)+h_{i}\left(H m l_{t}\right)+w_{i}\left(W m l_{t}\right) \\
+l_{i}\left(I m l_{t}\right)+\gamma_{i}\left(F k_{t}\right)+\delta_{i, n}\left(\sum_{01}^{13} D_{t}\right)+\varepsilon_{i t}
\end{gathered}
$$

The main difference from model 3 to model 1 is that now we are estimating one parameter for each portfolio $i$. Also, the control for systematic risk now is the local return (instead of the global return we used for our aggregate analysis). Once again our main interest is on the gamma parameter, the measure of the revaluation effect.

\footnotetext{
1 We did not estimate a model for the Dividend Yield using portfolios because the dataset for the dividend yield had too many missing variables. Thus we leave the estimation of the effects of foreign capitals on the cost of equity exclusive to the aggregate level.
} 
All the equations were estimated using two-stages GMM. ${ }^{2}$ To prevent any problems related to heteroskedasticity or serial autocorrelation, we employed Newey-West HAC standard errors. Our main assumption for estimating the APT is that the coefficients are time constant (unconditional).

\subsection{Results}

This section reports the results for the regression models estimated. For every regression, we report regression coefficients for each factor, Newey-West HAC robust standard errors in parenthesis, and the Hansen's J test for over-identifying restrictions, which tests for the validity of instruments and model specification. The null hypothesis of the test is that the instruments are valid, thus accepting the null hypothesis points to a correct specification of the model (Greene, 2003).

The column for Hj Fk reports the Hansens' J specification statistic for the extended model, including Fk as a regressor. The column $\mathrm{Hj}$ $\mathrm{b}$ reports the statistic for the baseline model, without including Fk as an additional explanatory variable. The objective is not to make a direct comparison between the extended versus the baseline model, but to show that after including Fk as an additional factor, the test for over-identifying restriction still provides evidence for correct specification. We report the p-value for the test, and not the chi-square test statistic. Thus, a p-value close to one implies a low probability of rejecting the null hypothesis of instrument validity, whereas a p-value $<0.05$ rejects the null hypothesis.

The return factors Beta, Smb, $\mathrm{Hml}, \mathrm{Wml}$ and $\mathrm{Iml}$ were included strictly as controls, to allow for a ceteris paribus effect of the Fk factor on returns. Therefore, the focus of the analysis is on the Fk parameter, labeled gamma (we are not directly interested on the effects of these control factors on returns). The same goes for time

2 The contemporaneous independent variables were used as instruments for estimating an unconditional APT. For models number 1 and 3, three one-period lagged variables were found to be relevant instruments (Fk, SMB and WML), so they were included in the estimation too, making the system slightly over-identified (19 parameters and 22 moments). For model 2, the lags of Fk and up to the second lag of the Dividend Yield were also used as instruments. 
dummies (these are not reported in the tables for parsimony). Thus, we comment essentially on the marginal effects of Fk.

\subsubsection{Aggregate analysis}

The table next brings the results for regression number 1 , in which we assessed the effects of foreign portfolio capital flows on aggregate stock market returns.

Table 5 - Aggregate stock market regression - GMM estimation with NeweyWest HAC std errors

\begin{tabular}{|c|c|c|c|c|c|c|c|c|c|}
\hline & gamma & alpha & beta & $S$ & $H$ & $w$ & $L$ & $H j f k$ & $H j b$ \\
\hline \multicolumn{10}{|c|}{ Aggregate Returns (Rm-rf) } \\
\hline 6-factors APT & $\begin{array}{l}.079^{\star \star *} \\
(.016)\end{array}$ & $\begin{array}{l}-.012^{\star \star \star} \\
(.002)\end{array}$ & $\begin{array}{l}.855^{\star \star *} \\
(.024)\end{array}$ & $\begin{array}{l}.219^{\star * *} \\
(.086)\end{array}$ & $\begin{array}{l}.014 \\
(.021)\end{array}$ & $\begin{array}{l}.022 \\
(.046)\end{array}$ & $\begin{array}{l}-.209^{\star \star \star} \\
(.066)\end{array}$ & 0.83 & 0.70 \\
\hline Global CAPM & $\begin{array}{l}.080^{\star * *} \\
(.023)\end{array}$ & $\begin{array}{l}-.013^{\star \star \star} \\
(.001)\end{array}$ & $\begin{array}{l}.891^{\star * \star} \\
(.026)\end{array}$ & . & . & . & . & 0.60 & 0.79 \\
\hline
\end{tabular}

*** Significant at 0.01 level; ${ }^{* *}$ Significant at 0.05 level; ${ }^{*}$ Significant at 0.1 level

The first row of the table reports the result for the APT model, including the five control factors (global beta, Smb, $\mathrm{Hml}, \mathrm{Wml}$ and Iml) plus the factor for foreign capital flows (Fk). On the second row, a simple Global CAPM model is also reported (the only control in this model is the global beta). Thus we can compare how the gamma coefficient for foreign capitals changes after adding other factors as controls.

A first interesting finding is that the global beta coefficient is 0.85 . The interpretation is that for a $1 \%$ change in global returns, the IBOVESPA index changes $0.85 \%$ (recalling that we used S\&P 500 returns as a proxy for global returns). As the Ibovespa's global beta is near to one, it has a near to one-to-one sensitivity to global returns, which is per se a first indication of the level of integration between the Brazilian stock market and the global stock market. The marginal effect of net foreign portfolio capital flows (Fk) on aggregate stock market returns (Rm-rf) is statistically significant and positive in the two model specifications (0.08). This first finding is in line with the revaluation effect hypothesis, which predicts a positive relationship between foreign portfolio capital flows and stock returns. 
Table 6 brings the result for regression number 2, in which we assessed the effect of foreign portfolio capitals on the dividend yield (a proxy for the cost of equity capital):

Table 6 - Cost of equity capital regression - GMM estimation with Newey-West HAC std errors

\begin{tabular}{lccccc}
\hline & gamma & alpha & beta & Hj fk & Hj b \\
\hline Cost of equity capital & & & & & \\
Dividend Yield & $-.024^{\star * *}$ & $.015^{\star * *}$ & $.784^{* * *}$ & 0.61 & 0.30 \\
& $(.001)$ & $(.003)$ & $(.061)$ & & \\
\hline
\end{tabular}

*** Significant at 0.01 level; ${ }^{* *}$ Significant at 0.05 level; ${ }^{*}$ Significant at 0.1 level

Alpha is the intercept, and beta is the one-period lag of the dividend yield. The marginal effect of net foreign portfolio capital flows (Fk), gamma, on the dividend yield is statistically significant and negative $(-0.024)$. In other words, foreign portfolio capitals are associated to a decline in the cost of equity capital.

The results for the dividend yield regression corroborate those from the aggregate stock market returns, because as stock prices rise, expected returns fall and the dividend yield is expected to drop (indeed they are negatively correlated, as shown in the Correlation Matrix in Table 3). Therefore, if foreign capitals increase stock returns, the marginal effect of foreign capitals on the dividend yield must be negative. This second finding also gives support to the revaluation effect hypothesis, and establishes a direct negative relationship between foreign portfolio capital flows and the cost of equity capital.

\subsubsection{Disaggregate analysis - portfolios}

Next, the results for each type of portfolio (economic sectors, risk and corporate governance) are discussed. The focus of the analysis is on the first column of Table 7, in which the regression coefficient for Fk (foreign capital flows) is reported (labeled gamma). 
Table 7 - Portfolio regressions (GMM estimation with HAC Newey-West standard errors)

\begin{tabular}{|c|c|c|c|c|c|c|c|c|c|}
\hline & gamma i & alpha $i$ & beta $i$ & si & $\mathrm{Hi}$ & $W i$ & $L i$ & $H j f k$ & $H j b$ \\
\hline \multicolumn{10}{|l|}{ Economic Sectors } \\
\hline \multirow[t]{2}{*}{ Cyclical consumption (Cyc) } & $.116^{\star \star \star}$ & $-.054^{\star \star \star}$ & $.817^{* \star *}$ & $.403^{\star \star \star}$ & -.080 & $-.094^{\star \star \star}$ & .135 & 0,79 & 0.62 \\
\hline & (.018) & $(.004)$ & $(.030)$ & $(.080)$ & $(.051)$ & $(.026)$ & $(.109)$ & & \\
\hline \multirow[t]{2}{*}{ Industrial goods (IG) } & $.128^{\star \star \star}$ & $-.025^{* \star *}$ & $.514^{\star \star \star}$ & $.511^{\star \star *}$ & -.108 & -.020 & -.133 & 0.71 & 0.51 \\
\hline & $(.045)$ & $(.003)$ & $(.038)$ & $(.089)$ & $(.067)$ & $(.025)$ & $(.117)$ & & \\
\hline \multirow[t]{2}{*}{ Basic materials (BM) } & $.082^{\star *}$ & $-.005^{\star \star}$ & $.995^{\star * *}$ & $.376^{\star \star \star}$ & $-.108^{\star \star}$ & .147 & $-239^{\star \star \star}$ & 0.81 & 0.64 \\
\hline & $(.037)$ & $(.002)$ & $(.031)$ & $(.040)$ & $(.054)$ & $(.113)$ & $(.074)$ & & \\
\hline \multirow[t]{2}{*}{ Real estate (RE) } & -.037 & $.003^{*}$ & $.668^{\star \star *}$ & $1.09^{\star \star \star}$ & -.024 & -.010 & $-.620^{\star * \star}$ & 0.75 & 0.60 \\
\hline & $(.037)$ & $(.002)$ & $(.040)$ & $(.053)$ & $(.036)$ & $(.051)$ & $(.057)$ & & \\
\hline \multirow[t]{2}{*}{ Public utilities (PU) } & $.068^{\star *}$ & $-.025^{* \star \star}$ & $.70^{\star \star \star}$ & .046 & $.295^{\star \star \star}$ & $-.083^{\star \star}$ & $.162^{\star}$ & 0.70 & 0.49 \\
\hline & (.029) & $(.001)$ & $(.030)$ & $(.076)$ & $(.043)$ & $(.038)$ & $(.090)$ & & \\
\hline \multirow[t]{2}{*}{ Telecom (TC) } & $-.258^{\star \star}$ & $-.021^{\star \star \star}$ & $.676^{* \star *}$ & .036 & $.185^{\star \star}$ & $-.093^{\star}$ & $.120^{*}$ & 0.69 & 0.66 \\
\hline & $(.023)$ & $(.004)$ & $(.049)$ & $(.066)$ & (.092) & $(.054)$ & $(.065)$ & & \\
\hline \multirow[t]{2}{*}{ Construction and transport (CT) } & -.115 & $-.028^{\star \star \star}$ & $.714^{\star \star \star *}$ & $.651^{\star \star \star}$ & -.068 & $.082^{\star}$ & $-.189^{\star \star}$ & 0.65 & 0.44 \\
\hline & $(.077)$ & $(.004)$ & $(.043)$ & $(.101)$ & $(.101)$ & $(.042)$ & $(.076)$ & & \\
\hline \multirow[t]{2}{*}{ Oil and gas (OG) } & $.077^{\star \star \star}$ & $.009^{*}$ & $1.14^{\star \star *}$ & .009 & -.060 & -.002 & $-.161^{*}$ & 0.71 & 0.86 \\
\hline & $(.026)$ & $(.005)$ & $(.031)$ & $(.091)$ & $(.040)$ & $(.034)$ & $(.097)$ & & \\
\hline \multirow[t]{2}{*}{ Non-cyclical consumption ( $\left.N \_c y c\right)$} & $-.206^{\star \star \star}$ & $.011^{\star \star \star}$ & $.578^{\star \star *}$ & $.330^{* \star *}$ & $-.105^{\star \star *}$ & -.027 & $-.150^{* \star *}$ & 0.68 & 0.65 \\
\hline & $(.034)$ & $(.002)$ & $(.019)$ & $(.046)$ & $(.025)$ & $(.028)$ & $(.052)$ & & \\
\hline \multicolumn{10}{|l|}{ Risk } \\
\hline \multirow[t]{2}{*}{ Beta 1 (low) } & $-.035^{*}$ & $.004^{* *}$ & $.385^{* \star *}$ & .133 & $.113^{* \star *}$ & .030 & -.00 & 0.70 & 0.53 \\
\hline & (.019) & $(.001)$ & $(.014)$ & $(.097)$ & $(.024)$ & $(.034)$ & $(.096)$ & & \\
\hline \multirow[t]{2}{*}{ Beta 2 (low-mid) } & $-.058^{\star \star}$ & $.013^{\star \star \star}$ & $782^{* \star *}$ & $.249^{* * *}$ & $-.157^{\star \star \star}$ & $.133^{\star \star \star}$ & $-.071^{\star \star \star}$ & 0.70 & 0.66 \\
\hline & $(.029)$ & $(.002)$ & $(.014)$ & (.022) & $(.020)$ & $(.017)$ & $(.025)$ & & \\
\hline \multirow[t]{2}{*}{ Beta 3 (mid-high) } & $.057^{\star \star \star}$ & -.003 & $1.00^{* * *}$ & -.044 & .037 & $-.047^{\star \star \star}$ & .009 & 0.67 & 0.75 \\
\hline & $(.017)$ & $(.002)$ & $(.009)$ & $(.031)$ & $(.023)$ & $(.015)$ & $(.033)$ & & \\
\hline \multirow[t]{2}{*}{ Beta 4 (high) } & $.081^{\star \star \star}$ & $-.053^{\star \star \star}$ & $1.25^{\star \star *}$ & $578^{* \star *}$ & $.061^{* * *}$ & $-.113^{\star}$ & $-.231^{*}$ & 0.79 & 0.63 \\
\hline & $(.023)$ & $(.004)$ & $(.046)$ & (.104) & $(.020)$ & $(.060)$ & $(.138)$ & & \\
\hline \multicolumn{10}{|l|}{ Corporate Governance } \\
\hline \multirow[t]{2}{*}{ Novo Mercado (NM) } & $.036^{*}$ & $-.013^{\star \star \star}$ & $.802^{* \star *}$ & $.446^{* \star *}$ & -.036 & $-.078^{\star}$ & -.066 & 0.72 & 0.52 \\
\hline & (.018) & $(.002)$ & $(.024)$ & $(.046)$ & $(.029)$ & $(.040)$ & $(.058)$ & & \\
\hline \multirow[t]{2}{*}{ N1 } & -.004 & -.001 & $.921^{* \star *}$ & $313^{* \star *}$ & $.065^{* * *}$ & $.127^{\star \star \star}$ & $-.195^{\star \star \star}$ & 0.64 & 0.79 \\
\hline & $(.025)$ & $(.002)$ & $(.014)$ & $(.027)$ & $(.022)$ & $(.030)$ & $(.035)$ & & \\
\hline \multirow[t]{2}{*}{ N2 } & -.032 & $.034^{\star \star \star}$ & $.661^{\star \star *}$ & $177^{\star \star \star}$ & .012 & $.082^{* *}$ & $-.177^{\star \star \star}$ & 0.75 & 0.57 \\
\hline & $(.024)$ & $(.002)$ & $(.022)$ & $(.062)$ & $(.021)$ & $(.036)$ & $(.057)$ & & \\
\hline \multirow[t]{2}{*}{ Tradicional Bovespa (TB) } & -.002 & .020 & $.947^{\star \star \star}$ & -.025 & $-.101^{\star \star *}$ & $-.029^{\star}$ & .024 & 0.67 & 0.80 \\
\hline & $(.002)$ & $(.020)$ & $(.008)$ & $(.035)$ & $(.024)$ & $(.015)$ & $(.039)$ & & \\
\hline
\end{tabular}

*** Significant at 0.01 level; ** Significant at 0.05 level; ${ }^{*}$ Significant at 0.1 level 


\section{Economic Sectors Portfolios}

The first interesting finding from regression model (3), as reported in Table 7, is that the effect of foreign portfolio capital flows on the returns of the various economic sectors portfolios varied both in sign and magnitude. Thus, the revaluation effect does not spillovers equally across different stocks, which is a first indication that a disaggregate analysis makes sense.

For five sectors, the marginal effect of foreign capitals on returns was statistically significant and positive (Cyclical consumption, Basic materials, Industrial goods, Public utilities and Oil and gas). For two sectors (Non-cyclical consumption and Telecommunications) the effect of foreign capitals on returns was statistically significant and negative. For the other two sectors (Real estate and Construction and Transport), the effect of foreign capitals on returns was not statistically different from zero.

The two sectors whose returns showed the highest sensitivity to foreign capitals were industrial goods and cyclical consumption $(0.13$ and 0.12 respectively). Basic materials (0.08) and Oil and gas (0.07) follow next, and finally Public utilities (0.06) was the sector for which returns showed the lowest (but positive) response to foreign capitals.

During the sample period covered by this study, the Brazilian economy experienced a notably consumption-based business cycle, in which the growth of the economy, especially between 2003 and 2010, was driven essentially by consumption expenditures and soaring commodity prices. Thus one might suggest that foreign investors considered the business cycle characteristic when designing their trading strategies, favoring economic sectors that were benefiting from the business cycle (which is the case especially for Cyclical consumption, Industrial goods, Basic materials and Oil and gas). ${ }^{3}$ The finding that the returns of Non-cyclical consumption and Telecommunications sectors decreased as a function of foreign portfolio capital flows suggests that some sectors (stocks) may be hindered by foreign flows. Maybe foreign investors reallocated capi-

\footnotetext{
${ }^{3}$ The revaluation effect measures only the sensitivity of returns to foreign flows, but not how much flow was allocated on each economic sector. Therefore, one can at best suggest, but not conclude that these sectors received more flows.
} 
tal towards sectors that were expected to benefit from the current business cycle (for example, from Non-Cyclical to Cyclical consumption), or foreign investors just sold their positions and invested somewhere else. Apart from such conjectures, what is most relevant is that there is evidence for a "devaluation effect" for these two sectors of economic activity.

\section{Risk Portfolios}

The analysis for the Risk portfolios considered four different portfolios, sorted according to the beta coefficient's proximity. Four portfolios were formed, ranging from low beta (lower 25\% quartile of the distribution), mid-low (26-50\% quartile), mid-high (51-74\% quartile) and high (75-99\% quartile). Thus, each portfolio has a different exposure to systematic risk: Beta $1($ low) is very little exposed, whereas the Beta 4 (high) is highly exposed. Indeed, by looking at the fitted beta parameters (third column), we see that the exposure to systematic risk (the magnitude of the beta coefficient) increases as we move from the Beta 1 portfolio $(b=0.38)$ towards the Beta 4 portfolio $(b=1.25)$.

The gamma coefficient, which measures the partial effect of net foreign portfolio capital flows on returns, is statistically significant for all four portfolios. The effect of foreign capitals on returns is negative for the Beta 1 (low) and Beta 2 (low-mid) portfolios (-0.035 and -0.058 respectively). On the other hand, for the Beta 3 (mid -high) and Beta 4 (high) portfolios, the effect of foreign capitals is positive ( 0.057 and 0.081 respectively).

Such a change in the sign of the parameters as we move from low-beta portfolios to high-beta portfolios is highly interesting. The interpretation is that for the portfolios bearing higher idiosyncratic risk (lower exposure to market returns), foreign capitals marginally decreased returns. Conversely, for the portfolios bearing more diversifiable risk (higher exposure to market returns), foreign capitals marginally increased returns. Such an evidence for the risk-sorted portfolios analysis suggests that the effect of foreign portfolio capital flows on stock returns is contingent on the level of systematic risk to which a given stock or portfolio is exposed. For portfolios (stocks) with mid-to-high covariance with market returns, the po- 
sitive revaluation effect holds. However, portfolios with low-to-mid covariance with market returns suffered a devaluation effect.

Also, comparing the magnitude of the marginal effects, we see that the high-beta portfolio (Beta 4) experienced a slightly higher revaluation effect when compared to the mid-to-high beta portfolio (Beta 3). For the low and mid-low beta portfolios (Beta 1 and Beta 2), the marginal effect of foreign capitals on returns is negative, but the Beta 2 portfolio experienced a higher devaluation effect. The analysis so far provides some indication that the marginal effect of foreign capital flows on stock returns increases as we move from low-beta assets to high-beta assets.

An important discussion regarding this finding is whether foreign investors are buying riskier stocks (high-beta stocks), or if foreign investors trading make stocks riskier. Or, in other words, the results call for a discussion on the direction of the causality effect. Considering that a stock with a low beta is a stock whose returns are less sensible to systematic risks, foreign investors should avoid holding such a stock. If institutional investors invest globally, and use different equity markets for hedging against systematic risk, there is no point for holding stocks insensible to the Brazilian stock market, because these stocks bear much idiosyncratic risk, which can't be diversified away.

The second possibility is that foreign investors induce higher volatility, which in turn makes stocks riskier. A higher volatility would increase risk and therefore increase expected returns. Although the main objective of the analysis is not to assess the effect of foreign flows on risk, we can do a simple and preliminary exercise for checking the effect of foreign capitals on risk by estimating a variance equation to evaluate the effect of foreign capitals on returns volatility. The following GARCH model was estimated:

$$
\sigma i_{t}^{2}=\omega+\alpha \sigma_{t-1}^{2}+\eta_{\varepsilon_{t-1}^{2}}^{2}+\gamma_{F k_{t}}
$$

The variance equation above was estimated for each risk portfolio $i$. We included the variable foreign portfolio capital flows (Fk) as an additional explanatory variable in the variance equation. The Table 8 reports the results: sigmal is the variance for portfolio Beta 1 (low), 
sigma 2 for portfolio Beta 2 (mid-low), sigma3 for portfolio Beta 3 (mid-high) and sigma4 for portfolio Beta 4 (high).

Table 8 - Variance equation - GARCH estimation

\begin{tabular}{lcccc|}
\hline & sigma1 & sigma2 & sigma3 & sigma4 \\
\hline Variance equation & & & & \\
Fk & $-.017^{\star \star \star}$ & -.008 & $-.012^{\star}$ & $-.034^{\star \star \star}$ \\
& $(.002)$ & $(.005)$ & $(.007)$ & $(.005)$ \\
\hline
\end{tabular}

The results from the GARCH exercise show that for three risk portfolios (Beta 1, Beta 3 and Beta 4) the effect of foreign capitals on the volatility is actually negative. For the Beta 4 (high) portfolio, foreign capitals had the most negative effect (-0.034), therefore foreign capitals exerted a higher reduction on the volatility of the portfolio exposed to higher systematic risk. Overall, this preliminary and simple analysis suggests that foreign capitals actually reduce the volatility of returns. Therefore, it appears to be more likely that foreign capital flows increase returns rather than make the portfolios riskier.

\section{Corporate Governance Portfolios}

The last part of the disaggregate analysis evaluated the effect of foreign capitals on corporate governance portfolios. Stocks were sorted according to the BMF\&Bovespa corporate governance classification, so the criteria for sorting each portfolio highly reflects firms' corporate governance practices. Novo Mercado (NM) segment includes firms observing the most advanced corporate governance practices, followed by N1 and N2 segments, which includes firms observing "intermediary-level" good practices, and lastly "Tradicional Bovespa" segment, which includes firms observing only basic practices and rules.

As the results from Table 7 show, the only corporate governance portfolio whose returns were found to be sensible to foreign portfolio capital flows was Novo Mercado (NM). For this portfolio, the marginal effect of foreign capitals on returns was statistically significant and positive (0.036). For the other three corporate governance portfolios, the effect of foreign capitals was not statistically different from zero. 
This finding suggests that only stocks from firms observing the best corporate governance standards (Novo Mercado) benefited from a positive revaluation effect. It could signal that foreign investors prefer to buy stocks from firms observing good corporate governance rules and practices, as it was the only portfolio whose returns were found to be indeed sensible to foreign investors trading. That makes sense if one considers that firms communicating information in a clearer way to investors by following best practices in corporate governance, as firms listed in the Novo Mercado segment are expected to do, can reduce asymmetries of information between managers and shareholders. Therefore, such stocks should exhibit better market performance, and these firms should be able to enjoy a lower cost of equity capital.

\section{Discussion}

The results from the aggregate analysis corroborated the revaluation effect hypothesis. Foreign portfolio capital flows caused aggregate stock market returns to increase, in line with theoretical predictions from partial equilibrium models (as in Henry, 2003) as well as with empirical findings from the international literature (as in Errunza \& Miller, 2000; Patro \& Wald, 2005, etc). The main theoretical rationale supporting such an empirical finding is that as a previously segmented market integrates to the global market, foreign investors are allowed to trade on the newly opened capital market, and the buying pressure from these investors drives stock prices upwards (Henry, 2000; Meurer, 2006).

A positive association between foreign portfolio capital flows and aggregate stock market returns was also reported by prior studies of the Brazilian market, as in Tabak (2003), Meurer (2006), Franzen et al. (2009), Reis, Meurer \& Da Silva (2010) and Sanvicente (2014). Therefore, our findings corroborate the results from these studies, providing updated evidence, as our analysis covers a more recent period. Moreover, we view our conceptualization of foreign portfolio flows as an additional risk factor in a Arbitrage Pricing Theory setting as a contribution, because by doing so we conciliate the literature on foreign capitals with the asset pricing methodology, and we 
also control for important return factors (Smb, Hml, Wml and Iml) which were absent in prior studies for the Brazilian case.

The coefficient found for the partial effect of foreign capitals on aggregate market returns (as well as for the portfolios as discussed later) is somewhat small (0.08), what could suggest a low sensibility of returns to foreign flows. However, putting methodologies in perspective, most of international studies employed event-study methods, in which the impact of foreign capitals was assessed immediately after a liberalization event or set of events (Patro \& Wald, 2005, Errunza, Christoffersen \& Miller, 2006). Building on the argument by Stulz (1999), the liberalization of an equity market is not best described as a one-shot event or a set of important regulatory marks, but is rather a process.

Foreign investors may start to trade on a previously segmented market after a given regulatory mark, but sustained investment depends on other factors, like macroeconomic stability and growth on the country level, and on corporate governance improvements and adoption of accounting best practices (internationally recognized) on the firm level (Stulz, 2005). Therefore, although event studies are useful to assess the short-term impact of liberalization on returns, given that the liberalization process takes time to occur, it is not likely that the revaluation effect on stock prices lasts only for such short periods.

A large number of Brazilian firms went public during the 20002010 decade, much influenced by the inflows of foreign capitals that became more abundant after the macroeconomic stabilization and regulatory improvements, which occurred by the end of the 1990s. As a broad process, the liberalization of the Brazilian equity market is still an ongoing process, which had an important development during the period between 2001-2013, exactly the period covered by this study. Our view is that the positive coefficient of net foreign capitals on aggregate market returns obtained in this study can be interpreted as the "average revaluation effect" during the 2001-2013 period.

As the time series cover thirteen years, it is clear that at some periods foreign investors withdrew from the Brazilian market (like during the financial turmoil of 2008), possibly causing a devalua- 
tion effect, and that in other periods buys exceeded sells, as it was actually the average figure for the period, because the average net flow was positive. Therefore, the revaluation effect was probably of a higher magnitude for some shorter sub-periods, as well as it was probably negative for some other periods. Unfortunately, our assumption of considering a constant parameter for foreign capitals when setting the APT model restricts our estimation to this "average revaluation effect". We discuss more on this when approaching the study's limitations.

The second finding from the aggregate analysis is that the marginal effect of foreign portfolio capital flows on the dividend yield was negative, what suggests that foreign flows drive the cost of equity capital downwards. This finding supports the first result from the aggregate stock market returns analysis: as stock price movements usually dominate the variations in the dividend yield (because firms like to keep dividends payments more or less constant over time), as foreign flows drive stock prices upwards, these flows should indeed drive the dividend yield downwards. This finding corroborates the results from Bekart and Harvey (2000), in which they reported a substantial drop in the dividend yield after emerging markets liberalized their equity market for foreign investors trading.

The disaggregate-level analysis, overall, also provided support in favor of the revaluation effect. In this analysis, we used some characteristics of stocks to sort assets in portfolios reflecting the sector of economic activity, level of exposure to systematic risk (betas) and corporate governance practices. Prior studies showed that some specific characteristics of assets play a mediating role between foreign portfolio capital flows and stock returns. Chari and Henry $(2004,2008)$ show that the revaluation effect can be split between a common shock to the equity market as a whole and a firm-specific shock. Patro and Wald (2005) and Errunza, Christoffersen and Miller (2006) provided evidence that size may mediate the revaluation effect. Because we found that the revaluation effect does not spillovers equally across different portfolios, our analysis provides support to the argument that the characteristics of the portfolios matter for understanding how foreign capital flows affect stocks' returns. 
Specific to the disaggregate analysis conducted in this study, we found evidence that the effect of foreign flows on returns differs across various sectors of economic activity. Overall, the sectors more directly affected by the consumption and commodities business cycle experienced by the Brazilian economy during 2001-2013 were also the portfolios whose returns were more sensible to foreign flows (cyclical consumption, basic materials, industrial goods and oil and gas). This finding may suggest that foreign investors observe the exposure of firms to macroeconomic conditions and the current business cycle when designing their trading strategies, making the sector of activity a relevant firm characteristic mediating the effect of foreign flows on returns.

Differently from prior studies, the results obtained suggested that some sector portfolios, namely Telecommunications and Noncyclical consumption, experienced a "devaluation effect" instead of a revaluation effect, as the marginal effect of foreign flows on returns was negative for these two portfolios. Although it is difficult to pin down concrete reasons to account for this devaluation, one possibility is that foreign investors reallocated capital to other sectors, in which the marginal product of capital was higher (or expected to be higher) due to the economic momentum.

Such a reallocation seems quite reasonable if we consider that the cyclical consumption portfolio experienced a positive revaluation effect whereas the non-cyclical consumption suffered a devaluation effect instead. As non-cyclical consumption is not likely to grow much during economic booms (for been non-cyclical), it could be more valuable for investors to allocate capital on firms from the cyclical consumption sector, which were benefiting from the current business cycle. Or rather, foreign investors just sold their equity positions on the firms from these sectors, investing somewhere else.

The second part of the disaggregate analysis evaluated how foreign capital flows affected returns for risk-sorted portfolios, by grouping stocks using the proximity of their Beta coefficient. The evidence we found suggests that foreign investors are likely to be investing in such ways to follow the IBOVESPA index, as the returns of mid-high and high beta portfolios showed a positive sensitivity with respect to foreign capitals. On the other hand, both low and low-mid beta 
portfolios experienced a devaluation effect from foreign capitals, as the marginal effect of foreign capitals on returns was negative.

These findings are reasonable if we consider the hedging behavior of foreign investors. Institutional investors, hedge funds, mutual funds, etc, invest globally seeking to diversify the risk from their portfolios. Therefore, one should expect foreign investors to prefer mid to high beta portfolios instead of low to mid portfolios, because portfolios with a higher covariance with market returns bear diversifiable risk, whereas portfolios with low covariance with market returns carry too much idiosyncratic risk.

The literature proposes that when foreign investors start to trade on a previously segmented equity market, the risk stemming from the financial assets becomes shared between domestic and international investors (Errunza \& Miller, 2000; Henry, 2000). The positive revaluation effect we found for the high beta portfolios corroborates the risk sharing hypothesis, as the positive marginal effect of foreign flows on high beta portfolios signals an average buying pressure. On the other hand, because low beta portfolios were negatively affected by foreign flows, one may suggest that the risk sharing does not contemplate all stocks or portfolios in the market: the negative effect probably stems from a selling pressure, what could signal that for stocks with low covariance with market returns, foreign investors left the risk to be carried by domestic investors alone.

The study also provided preliminary evidence that foreign portfolio capital flows marginally decrease the riskiness of beta-sorted portfolios, because the marginal effect of foreign capital flows on the volatility of returns was found to be negative for three out of four beta-sorted portfolios. Our findings oppose to prior research which has suggested that foreign portfolio capital flows increase the volatility of returns in emerging stock markets, causing negative implications for resource allocation and productive efficiency (Singh \& Weisse, 1998). To some authors, foreign institutional investors are considered mere speculators, whose speculative behavior instead of causing stabilization and auto-correction of prices, often lead to processes characterized as self-referred, instable and disconnected from economic fundamentals (Coutinho \& Belluzo, 1996). In contrast, our analysis shows that foreign flows increase stock returns, drive the cost of equity downwards, and on top of that, there is a 
first indication that these benefits do not come at the expenses of a higher volatility of returns.

The last part of the disaggregate analysis evaluated the effect of foreign flows on the returns of portfolios sorted by the level of corporate governance. The findings suggest that firms observing the best corporate governance standards, exactly those listed in the Novo Mercado segment of Bovespa, experienced a positive revaluation effect. This result is in line with prior research too, as good corporate governance practices minimize asymmetries of information, attracting foreign institutional investors (Stulz, 2005).

Franzen et al. (2009), Meurer (2006) and Sanvicente (2014) discussed the causality relationship between foreign capitals and stock market returns. The results presented in this study are not directly informative with respect of the direction of the causality, because the asset-pricing model used to evaluate the effect of foreign capital flows on returns considered only the contemporaneous correlation between foreign flows and returns. However, regardless of the fact that higher returns may induce foreign investment, and foreign investments can in turn induce continuity in higher returns, since foreign capitals must enter or leave the stock market exerting a buying or selling pressure on the stock prices, the contemporaneous correlation is likely to be always in place.

Moreover, the feedback-trading hypothesis assumes in some extent that institutional investors believe that past returns are good predictors for future returns. If we analyze it under the perspective of the Market Efficiency Hypothesis, stock returns actually follow a random walk (Fama, 1970). As foreign investors are usually well-informed institutional investors, it is reasonable to expect that they gauge information on future corporate profits using more complex information sources than past returns. Thus it is more likely that they are better informed than local investors, and just anticipate good investing opportunities, buying stocks and driving returns upwards. As the results found in this study are supportive of this last possibility, they corroborate in some extent the information contribution argument. 


\section{Conclusions, limitations and further research}

The objective of this study was to analyze the impact of foreign portfolio capital flows on the stock returns of Brazilian listed firms. First, an aggregate analysis was conducted, in which we assessed the effect of foreign portfolio capital flows on aggregate stock market returns, by employing a 6-factors APT model (including foreign portfolio capital flows as an additional risk factor). Foreign flows marginally increased aggregate market returns, providing support to the revaluation effect hypothesis. In a second aggregate analysis, we found that foreign flows marginally decreased the cost of equity capital (dividend yield) of the IBOVESPA index, reaffirming the results obtained in the aggregate stock returns analysis.

In the second part of the study, a disaggregate analysis was conducted, in which portfolios of stocks were sorted according to some characteristics of the stocks (sector of economic activity, level of exposure to systematic risk and level of corporate governance). The results from the disaggregate analysis provided evidence that such characteristics affected the relationship between foreign flows and returns, because the marginal effect of foreign portfolio capital flows on returns differed across the various portfolios.

For the portfolios sorted by sector of economic activity, we found that foreign flows increased the returns for those sectors more exposed to the current economic momentum (cyclical consumption, industrial goods, basic materials and oil and gas), a business cycle marked by consumption growth and soaring commodity prices. For two sectors, namely Telecommunications and Non-Cyclical consumption, the effect of foreign flows on returns was negative, suggesting that the positive side of the revaluation effect does not spillovers equally across all assets: some assets may suffer from a "devaluation effect".

Our analysis on the corporate governance portfolios suggests that firms following the best corporate governance practices, exactly those listed in the Novo Mercado segment, were rewarded by foreign investors, as the marginal effect of foreign flows on returns was positive. For firms following lower corporate governance standards, the revaluation effect was not statistically different from zero. 
For the risk-sorted portfolios, we found that the mid-high and high beta portfolios experienced a positive revaluation effect, whereas the low and low-mid portfolios suffered a "devaluation effect". Our view is that this result is consistent with a hedging behavior from foreign investors: there is no reward for bearing strictly Brazilian idiosyncratic risk (low beta assets), but mid to high beta stocks, whose returns have a high covariance with the local market returns, are useful to hedge against global systematic risk. Additionally, we conducted a simple exercise to check whether foreign flows increased the returns of high beta assets, or actually increased the volatility of returns, making betas higher. The results from this exercise provided a first indication that foreign portfolio capital flows reduce the volatility of returns, suggesting that indeed foreign investors are likely to be buying high beta stocks.

Overall, the results from our study led us to conclude that foreign portfolio capital flows are more associated to increases than to decreases in returns. In other words, for the aggregate market and for the majority of portfolios for which the effect of foreign flows on returns was statistically different from zero, the revaluation effect prevails over the devaluation effect. But a word of caution is welcome: foreign flows may harm some classes of assets, namely those bearing high idiosyncratic risk (low betas) and those from economic sectors not benefiting from the current economic momentum.

Also, foreign portfolio capital flows were found to marginally decrease the cost of equity capital and marginally decrease the volatility of returns, supporting the risk-sharing hypothesis. Therefore, our study brings good news for those who see a bright side in financial globalization, but also leaves a word of caution, as foreign flows may cause devaluation effects too. On the other hand, our findings don't lend much support for those willing to strongly criticize foreign portfolio investments, as we did not find evidence that foreign flows disrupted stock market efficiency through increased volatility: our preliminary evidence actually supports the contrary.

The study had some important limitations. The main variable used to measure foreign capitals was an aggregate measure (total flows to the stock market), instead of a portfolio-level measure, because data on the flow of foreign investments going to each firm specifically was not publicly available. 
Also, we did not investigate in detail the feedback-trading hypothesis for the relationship between foreign capitals and stock returns. Further studies could combine time series analysis (as VAR and VECM) with asset pricing models to give a better treatment for this possible relationship. We assessed the importance of some asset-specific characteristics in affecting the relationship between foreign flows and returns, like sector of activity, exposure to risk and corporate governance, but other characteristics might be important too, like asset size, liquidity, growth opportunities, etc. Further studies could include these asset specific characteristics in the analysis.

Finally, for estimating the unconditional APT equation, we assumed that the effect of foreign portfolio capitals on stock returns is constant. Clearly, this is a simplification, because if the integration of an equity market to the global market is a process that takes time to occur, one may suspect that the revaluation effect varies through time (possibly having a downward trend) instead of being a constant. Further studies could test conditional models, allowing the parameter for foreign flows to vary, employing more robust methodologies to estimate such time-varying parameters.

\section{References}

AMIHUD, Y. Illiquidity and stock returns: cross-section and time-series effects. Journal of financial markets, 5(1), 31-56, 2002.

BACEN - Central Bank of Brazil. Sistema gerador de series temporais. Access in: January, 2015.

BEKAERT, G., \& HARVEY, C. R. Foreign speculators and emerging equity markets. The Journal of Finance, 55(2), 565-613, 2000.

BEKAERT, G., HARVEY, C. R., \& LUMSDAINE, R. L. The dynamics of emerging market equity flows. Journal of International money and Finance,21(3), 295-350, 2002.

CHARI, A., \& HENRY, P. B. Risk sharing and asset prices: evidence from a natural experiment. The Journal of Finance, 59(3), 1295-1324, 2004.

CHARI, A., \& BLAIR HENRY, P. Firm-specific information and the efficiency of investment. Journal of Financial Economics, 87(3), 636-655, 2008.

CHRISTOFFERSEN, P., CHUNG, H., \& ERRUNZA, V. Size matters: The impact of financial liberalization on individual firms. Journal of International Money and Finance, 25(8), 1296-1318, 2006.

COCHRANE, J. H. Asset Pricing. Princeton University Press, 2001.

COUTINHO, L., \& BELLUZZO, L. G. Desenvolvimento e estabilização sob finanças globalizadas. Economia e Sociedade, 7, 129-54, 1996.

Estud. Econ., São Paulo, vol.45, n.4, p. 859-895, out.-dez. 2015 
DAMODARAN, A. Avaliação de empresas. Pearson Prentice Hall, 2007.

ERRUNZA, V., \& LOSQ, E. International asset pricing under mild segmentation: Theory and test. The Journal of Finance, 40(1), 105-124, 1985.

ERRUNZA, V., \& LOSQ, E. Capital Flow Controls, International Asset Pricing, and Investors' Welfare: A Multi Country Framework. The Journal of Finance, 44(4), 1025-1037, 1989.

ERRUNZA, V. R., \& MILLER, D. P. Market segmentation and the cost of the capital in international equity markets. Journal of Financial and Quantitative analysis, 35(04), 577-600, 2000.

FAMA, E. F. Efficient capital markets: A review of theory and empirical work*. The journal of Finance, 25(2), 383-417, 1970.

FOERSTER, S. R., \& KAROLYI, G. A. The long-run performance of global equity offerings. Journal of Financial and Quantitative Analysis, 35(04), 499-528, 2000.

FRANZEN, A., MEURER, R., GONÇALVES, C. E. S., \& SEABRA, F. Determinantes do fluxo de investimentos de portfólio para o mercado acionário brasileiro. Estudos Econômicos (São Paulo), 39(2), 301-328, 2009.

FRATZSCHER, M. Capital flows, push versus pull factors and the global financial crisis. Journal of International Economics, 88(2), 341-356, 2012.

GREENE, W. H. Econometric analysis. Pearson Education India, 2003.

HENRY, P. B. Stock market liberalization, economic reform, and emerging market equity prices. The Journal of Finance, 55(2), 529-564, 2000.

HENRY, P. B. Capital account liberalization, the cost of capital, and economic growth (No. w9488). National Bureau of Economic Research, 2003.

MEURER, R. Fluxo de capital estrangeiro e desempenho do IBOVESPA.Revista Brasileira de Finanças, 4(1), 345-361, 2006.

NEFIN - Brazilian Center for Research in Financial Economics of the University of Sao Paulo. Financial data. Available at: http://nefin.com.br. Access in: January, 2015.

PATRO, D. K., \& WALD, J. K. Firm characteristics and the impact of emerging market liberalizations. Journal of banking \& finance, 29(7), 1671-1695, 2005.

ROGOFF, K., WEI, S. J., \& KOSE, M. A. Effects of financial globalization on developing countries: some empirical evidence (Vol. 17). Washington, DC: International Monetary Fund, 2003.

REIS, L., MEURER, R., \& DA SILVA, S. Stock returns and foreign investment in Brazil. Applied Financial Economics, 20(17), 1351-1361, 2010.

SANVICENTE, A. Z. The foreign capital flows and the behavior of stock prices at BM\&FBovespa. BAR-Brazilian Administration Review, 11(1), 86-106, 2014.

SINGH, A., \& WEISSE, B. A. Emerging stock markets, portfolio capital flows and long-term economie growth: Micro and macroeconomic perspectives. World Development, 26(4), 607-622, 1998.

SINGH, A. Capital account liberalization, free long-term capital flows, financial crises and economic development. Eastern Economic Journal, 191-216, 2003.

SMART, S. B., GITMAN, L. J., \& MEGGINSON, W. L. Corporate finance. Thomson South-Western, 2007.

STULZ, R. M. Globalization, corporate finance, and the cost of capital. Journal of applied corporate finance, 12(3), 8-25, 1999.

STULZ, R. M. The limits of financial globalization. The Journal of Finance, 60(4), 1595-1638, 2005.

TABAK, B. The random walk hypothesis and the behaviour of foreign capital portfolio flows: the Brazilian stock market case. Applied Financial Economics, 13(5), 369-378, 2003. 